\title{
Gangguan Mutisme Selektif Anak di Taman Kanak-kanak
}

\author{
Ahmad Tibyanul Masholeh", Tri Erniawati ${ }^{2}$ \\ ${ }^{1}$ TK DWP 3 Bendungan Pasuruan, ${ }^{2}$ TK Model Malang \\ E-mail: tibyanul27@gmail.com 082335449548
}

\begin{abstract}
The purpose of this study is (1) to describe the general picture of Selective Mutism disorders in research subjects, (2) to describe the factors causing the subject to experience Selective Mutism disorders, (3) to describe the efforts made by teachers and parents to deal with subjects with Selective Mutism disorders. . This study uses a qualitative description. The analysis used in this study came from the interactive model of analysis by Hubberman and Milles. Data collection is done by observation, interview and documentation techniques. Based on the results of the study it was found that children experience Selective Mutism disorders. Children tend to be quiet when at school, while at home children are more active. The teacher's way of dealing with children who have Selective Mutism disorders is by doing an interactive approach to children. Parents also often have to introduce children to the new environment.
\end{abstract}

Keywords:n Disorders; Selective Mutism; Children

\begin{abstract}
Abstrak: Tujuan penelitian ini adalah (1) mendeskripsikan gambaran umum tentang gangguan Mutisme Selektif pada subjek penelitian, (2) mendeskripsikan faktor-faktor penyebab subjek mengalami gangguan Mutisme Selektif, (3) mendeskripsikan upaya yang dilakukan guru dan orang tua untuk mengatasi subjek dengan gangguan Mutisme Selektif. Penelitian ini menggunakan deskripsi kualitatif. Analisis yang digunakan dalam penelitian ini berasal dari model interaktif analisis Hubberman dan Milles. Pengumpulan data dilakukan dengan teknik observasi, wawancara dan dokumentasi. Berdasarkan hasil penelitian ditemukan bahwa anak mengalami gangguan Mutisme Selektif. Anak cenderung diam ketika di sekolah, sedangkan di rumah anak lebih aktif. Cara guru untuk mengatasi anak yang memiliki gangguan Mutisme Selektif adalah dengan cara melakukan pendekatan secara interaktif kepada anak. Orang tua juga harus sering mengenalkan anak dengan lingkungan baru.
\end{abstract}

Kata Kunci: Gangguan; Mutisme Selektif; Anak

Perkembangan bahasa pada anak usia dini tidak bisa terlepas dari peran orang tua. Hal ini dikarenakan proses awal bahasa pada anak adalah dengan mencontoh bahasa yang anak dengar setiap hari. Oleh karena itu orang tua harus mampu memberikan contoh yang baik dalam berkomunikasi. Morrison (2016 : 458) menyatakan perkembangan bahasa dimulai saat anak lahir, karena pada saat anak lahir kedunia suara yang pertama di keluarkan adalah suara tangisan. Menangis merupakan cara anak berkomunikasi dengan orang tuanya dan orang di sekitarnya. 
Kemampuan berbicara anak mulai berkembang saat memasuki lembaga pendidikan prasekolah seperti Taman Kanak - kanak. Anak usia 4-5 tahun menunjukkan ketertarikan untuk bersosialisasi dan berbicara kepada orang lain agar dapat mengungkapkan perasaan dan keinginannya. Hurlock (1978 : 177) menyatakan bahwa berbicara merupakan sarana untuk berkomunikasi yang penting bagi kehidupan sosial anak. Melalui komunikasi anak akan dapat menyampaikan pikiran, perasan maupun keinginanya. Fenomena tutup mulut atau tidak mau berbicara untuk mengungkapkan pendapatnya bukanlah sikap dan tindakan yang membawa kemajuan ilmu kepada anak didik. Sikap seperti ini bisa disebabkan oleh kurangnya percaya diri, perasaan tidak nyaman pada lingkungan barunya dan lebih menutup diri.

Rasa kurang percaya diri merupakan sikap anak yang tidak sanggup menguasai dirinya dan tidak sanggup mengendalikan dirinya. Kepercaan diri yang baik membuat anak mudah bergaul dan mengekspresikan potensi yang dimilikinya. Anak yang mampu berinteraksi dengan lingkungan sosialnya akan lebih berani menampakkan dirinya secara apa adanya, karena orangorang yang percaya diri telah benar-benar memahami dan mempercayai kondisi dirinya, sehingga telah bisa menerima keadaan dirinya apa adanya. Gangguan komunikasi pada anak usia dini biasaya sering ditemui pada lingkungan taman kanak-kanak. Biasanya gangguan yang sering di temui adalah Mutisme Selektif atau gangguan berbicara.

Berdasarkan observasi pada tanggal 30 Juli - 17 September 2018 ditemukan adanya seorang anak di kelompok A di KB - TK Model Kota Malang yang memiliki masalah dalam bersosialisasi dengan orang-orang di lingkungan TK. Anak tersebut berinisial EL, EL sangat jarang sekali untuk berbicara ketika berada di sekolah, EL hanya diam dan tak mau bermain bersama teman-temannya. EL bahkan sering tidak mau mengikuti kegiatan di luar ruangan.

Mutisme Selektif adalah gangguan berkomunikasi yang biasanya dijumpai pada anak yang memilih tidak berbicara pada situasi tertentu atau orang tertentu, meskipun ia mampu. Misalnya, anak tidak mau berbicara di sekolah, padahal jika di rumah atau bersama temannya, ia banyak bicara. Gangguan ini umumnya dimulai sebelum anak berusia lima tahun, namun baru disadari saat anak mulai bersekolah. Tanda-tanda Mutisme Selektif diantaranya adalah selalu gagal berbicara pada situasi tertentu, misalnya di depan umum atau di depan kelas. Gejala ini berlangsung setidaknya selama sebulan setelah bersekolah dan bukan pada awal masuk sekolah akibat anak masih belum terbiasa. Gangguan bicara ini bukan karena anak tidak mampu menguasai materi atau karena tidak nyaman, bukan karena masalah dalam berbicara (misalnya gagap) dan bukan termasuk gangguan jiwa. Namun, dalam panduan tentang gangguan jiwa internasional disebutkan bahwa anak dengan gangguan Mutisme Selektif sering juga mengalami gangguan kecemasan, sangat pemalu, takut dengan lingkungan sosial, dan lebih menarik diri. 


\section{METODE}

Penelitian ini menggunakan metodologi kualitatif dengan bersifat deskriptif dengan pendekatan studi kasus. Penelitian kualitatif adalah penelitian yang bermaksud untuk memahami fenomena tentang apa yang dialami oleh subjek penelitian misalnya perilaku, persepsi, motivasi, tindakan, dll. Bogdan dan Taylor (Moleong, 2007: 4) mengartikan bahwa metodologi kualitatif sebagai prosedur penelitian yang menghasilkan data deskriptif berupa kata-kata tertulis atau lisan dari hasil pengamatan. Pendekatan ini diarahkan pada latar dari individu tersebut secara holistik. Jadi dalam hal ini tidak boleh mengisolasikan individu atau organisasi ke dalam variabel atau hipotesis, tapi perlu memandangnya sebagai bagian dari suatu keutuhan. Teknik pengumpulan data yang digunakan adalah wawancara, observasi dan dokumentasi. Penelitian dilaksanakan di KB - TK Model Kota Malang dan tempat tinggal subjek penelitian yang beralamat di Desa Randugading Rt 12 Rw 03 Kecamatan Tajinan Kabupaten Malang.

Analisis data yang digunakan dalam penelitian ini adalah analisis data model interaktif Milles dan Hubberman dimana terdapat tiga komponen utama yaitu kondensasi, pengajian data, dan penarikan kesimpulan/verifikasi. Berikut adalah gambar model interaktif:

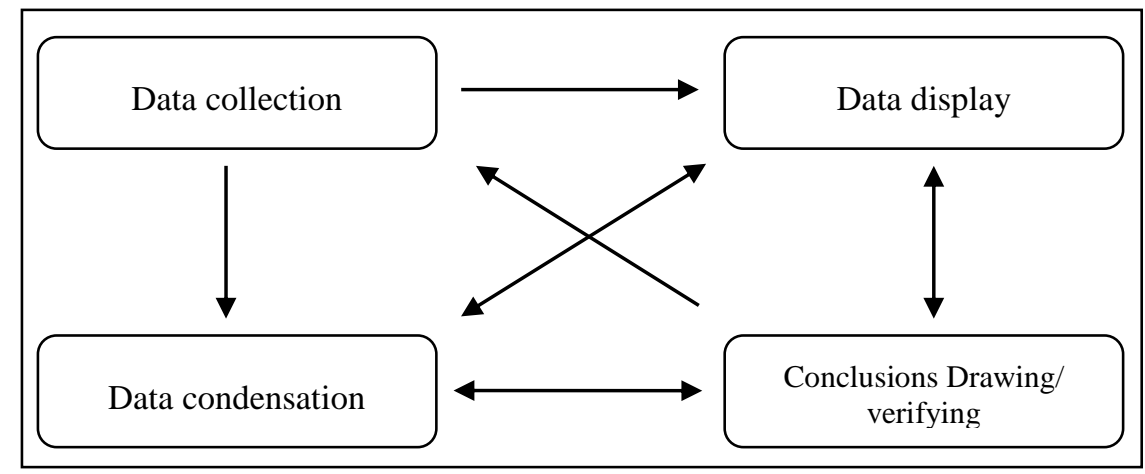

Gambar 1 : Komponen-komponen Analisis Data Model Interaktif (Milles dan Hubberman: 2017)

Uji keabsahan data dalam penelitian menggunakan teknik triangulasi. Triangulasi data adalah teknik pemeriksaan data yang memanfaatkan sesuatu yang lain diluar data tersebut untuk keperluan pengecekan atau sebagai pembanding data tersebut (Moleong, 2007: 330).

\section{HASIL}

Bedasarkan hasil observasi dan wawancara dengan guru dan orangtua diperoleh data bahwa terdapat gambaran umum tentang gangguan Mutisme Selektif, faktor-faktor penyebab dan upaya yang dapat di lakukan guru dan orang tua untuk mengatasi anak dengan gangguan Mutisme Selektif .

\section{Gambaran umum tentang gangguan Mutisme Selektif (Selective mutism)}


Gambaran umum tentang gangguan Mutisme Selektif pada anak yang dimaksudkan adalah sikap dan cara komunikasi anak yang ditunjukan selama proses penelitian. Berdasarkan hasil observasi dan wawancara, di temukan 5 gejala Mutisme Selektif yang ditunjukan subjek penelitian yaitu sebagai berikut : 1) ketika di sekolah anak lebih cenderung diam bahkan tidak mau berbicara, sedangkan di rumah anak dapat berbicara dengan bebas 2) anak lebih memilih menggunakan bahasa isyarat dengan menepuk dan menarik baju. 3) anak merespon pada orang tertentu 4) anak akan mau berbicara di lingkungan sekolah apabila anak diberikan dorongan dan nasehat, namun itu berlangsung sebentar. 5) anak kesulitan berkomunikasi dengan teman baru.

Anak bersedia berbicara di lingkungan sekolah apabila diberikan motivasi oleh guru kelas. Guru berusaha mengajak anak berkomunikasi, dengan melatih anak untuk merespon pertanyaan yang diajukan, sehingga anak bersedia berbicara lebih aktif. Temuan ini di buktikan dengan hasil catatan lapangan dan wawancara yang sudah peneliti lakukan sebagai berikut, ketika teman-teman yang lain mengambil daun-daun kecil, EL tidak mau menggambil daun tersebut. Anak lebih memilih untuk bermain dengan teman dekatnya dan tidak mau bermain dengan teman yang lainnya. Temuan ini di buktikan dengan hasil catatan lapangan dan wawancara yang sudah peneliti lakukan sebagai berikut, setelah EL menyelesaikan tugas, guru sentra memperbolehkan EL bermain APE di dalam kelas. Pada kegiatan bermain ini, EL lebih memilih bermain sendiri dari pada bermain dengan teman-temannya.

\section{Faktor-faktor penyebab gangguan Mutisme Selektif (Selective mutism)}

Faktor-faktor penyebab gangguan Mutisme Selektif dalam penelitian ini yaitu berasal dari dalam maupun dari luar diri anak. Berdasarkan hasil observasi dan wawancara, ditemukan 4 faktor penyebab gangguan Mutisme Selektif pada anak, yaitu sebagai berikut : 1) rasa malu dan kurang percaya diri yang sangat besar membuat anak tidak mau berbicara. 2) anak jarang bermain di luar lingkungan rumah. 3) guru kurang memberikan apresiasi ketika anak mau berbicara. 4) orang tua melarang anak untuk main di luar rumah.

Rasa malu dan kurang percaya diri yang sangat besar yang membuat anak tidak mau berbicara. Temuan ini di buktikan dengan hasil catatan lapangan dan wawancara yang sudah peneliti lakukan sebagai berikut, ketika guru melakukan presensi, EL menjawab dengan suara lirih. Anak kurang berinteraksi di luar rumah, temuan ini dibuktikan dengan hasil catatan lapangan dan wawancara yang peneliti lakukan sebagai berikut, EL lebih memilih bermain bola dalam rumah. Menurut penjelasan orangtua EL, EL sangat jarang sekali beraktivitas diluar rumah. Ketika beraktivitas di sekolah, anak mau berbicara ketika di berikan motivasi oleh guru kelas. 
Bentuk pola asuh yang kurang tepat ditunjukan dengan melarang anak untuk bermain dan berkomunikasi dengan orang yang baru dikenal. Hasil catatan wawancara sebagai berikut "Hubungan EL dengan keluarga di rumah sangat baik. EL anak yang sangat antusias ketika ada sepupunya mau main kerumah. Hanya saja ketika EL bermain di luar rumah kadang kami larang, karena rumah kami kan langsung ke jalan raya. Kami takut terjadi hal-hal yang tidak di inginkan".

\section{Upaya yang dapat di lakukan dengan gangguan Mutisme Selektif (Selective mutism)}

Upaya yang dilakukan guru dan orangtua dalam mengatasi gangguan Mutisme Selektif dalam penelitian adalah cara guru dan orang tua untuk menangani dan mengatasi anak dengan gangguan Mutisme Selektif. Berdasarkan hasil observasi dan wawancara yang dilakukan peneliti selama di lapangan, ditemukan 6 upaya yang dapat di lakukan yaitu sebagai berikut : 1) Memberikan nasehat pada anak dan motivasi pada orang tua. 2) Memberikan apresiasi ketika anak komunikatif. 3) Guru lebih selektif untuk memilih pertanyaan kepada anak. 4) Melakukan konsultasi dengan orang tua anak secara rutin. 5) Melakukan pendekatan yang intensif dengan anak. 6) Sering mengajak atau mengenalkan anak dengan lingkungan baru.

\section{PEMBAHASAN}

Subjek ketika di sekolah lebih cenderung diam bahkan tidak mau berbicara, sedangkan di rumah subjek dapat berbicara secara bebas dan semaunya. Berdasarkan penelitian dimana subjek lebih bebas berbicara ketika berada di lingkungan rumah dari pada berada di lingungan luar rumah seperti disekolah. Ketika berada di lingkungan sekolah anak lebih sering menunjukan sikap diamnya dan tak mau berbicara. hal tersebut sesuai dengan teori American Psychiantric Asosiai dalam Camposano (2011:46) bahwasanya gangguan Mutisme Selektif (Selctive Mutism) merupakan gangguan berkomunikasi yang biasanya dijumpai pada anak yang memilih tidak berbicara pada situasi tertentu atau orang tertentu, meskipun anak mampu. Misalnya, anak tidak mau berbicara disekolah. Padahal jika di rumah atau bersama temannya, anak banyak bicara.

Subjek lebih memilih menggunakan bahasa isyarat ketika berada di lingkungan luar rumah. Temuan tersebut dikuatkan dengan teori menurut Utnick dalam Yanuarini (2016), yang menyebutkan bahwasanya anak dengan ganguan Mutisme Selektif (Selctive Mutism) dapat dibagi menjadi 4 tahap yang salah satunya menyebukan bahwa moderately severe, subjek lebih memilih berkomunikasi dengan bahasa non verbal (dengan gesture dll). Subjek dalam berkomunikasi menggunakan bahasa isyarat atau symbol non verbal, baik menggunakan isyarat mulut maupun gerak tubuh. Subjek mau berbicara di lingkungan sekolah apabila subjek diberikan motivasi dan nasehat, namun itu berlangsung sebentar. Temuan tersebut diperkuat 
dengan teori menurut Hurlock (1978) bahwasanya terdapat beberapa kondisi yang menimbulkan perbedaan dalam belajar berbicara atau mengembangkan kemampuan berbahasa, salah satunya yaitu motivasi dan keinginan berkomunikasi. Subjek berbicara apabila didorong dan diberi motivasi oleh guru untuk mau berbicara.

Subjek memilih teman untuk diajak main dan tidak mudah berteman dengan teman baru. Temuan tersebut diperkuat dengan teori menurut Hurlock (1978) yang menyatakan beberapa kondisi yang menimbulkan perbedaan dalam belajar berbicara atau mengembangkan kemampuan bahasa, salah satunya yaitu hubungan dengan teman sebaya. Subjek menunjukan kedekatan dengan beberapa teman saja karena beberapa teman saja yang membuat subjek merasa nyaman dan cara berkomunikasinya juga sangat bervariatif. Rasa malu dan kurang percaya diri membuat subjek tidak mau berbicara. Temuan tersebut diperkuat dengan teori Reber (2010) menyatakan dalam kasus anak yang menderita gangguan Mutisme Selektif ini, saat disekolah guru biasa mengkaitkan keadaan ini dengan sifat pemalu. Mutisme Selektif diklasifikasikan sebagai gangguan pada anak, ditunjukkan oleh kegagalan berbicara dalam situasi sosial spesifik. Pola asuh orang tua yang melarang subjek untuk main di luar rumah dan berkomunikasi dengan orang-orang baru dikenal, sesuai dengan teori Nieves, dkk, (2012) bahwa Mutisme selektif dihubungkan dengan berbagai faktor penyebab, seperti adanya orang tua yang sering melarang anaknya untuk berinterkasi dengan orang baru yang membuat anak menjadi tidak berani untuk berinteraksi dengan orang baru, sehingga anak menjadi penakut. Guru harus tepat dalam menstimulasi kemampuan komunikasi anak. Temuan tersebut diperkuat dengan teori Suhartono (2005: 122), bahwa pengembangan bicara anak yaitu usaha meningkatkan kemampuan anak untuk berkomunikasi secara lisan sesuai dengan situasi yang dimasukinya. Jadi, tujuan utama dalam pengembangan bicara anak adalah agar anak memiliki keterampilan berbicara yang baik serta memiliki kemampuan berkomunikasi secara lisan dengan lancar.

Guru dan orangtua melakukan komunikasi secara bersinambung mengenai perkembangan bahasa anak, tujuannya agar stimulus yang di berikan guru selama di sekolah juga dapat di terapkan di rumah. Temuan tersebut diperkuat dengan teori menurut Santrock (2012) bahwa sekolah juga harus mengadakan kerjasama dengan orang tua melalui komunikasi secara rutin. Tujuannya agar orang tua memahami perkembangan bahasa anak selama di sekolah. Melakukan pendekatan yang intensif dengan subjek. Guru intensif melakukan pendekatan kepada subjek, dengan tujuan agar guru memahami perkembangan anak. Temuan tersebut diperkuat dengan teori menurut Compasono (2011:53) yang mewujudkan bahwa gangguan Mutisme Selektif dimulai saat anak mulai bersekolah hingga guru wajib untuk mengenali gejala yang ditimbulkan oleh anak. Guru juga harus dapat meminimalisir kondisi 
kecemasan anak ketika berada di sekolah. Lingkungan sekolah juga dapat menjadi faktor yang dapat mengatasi gangguan Mutisme Selektif.

\section{SIMPULAN}

Berdasarkan fokus dan tujuan penelitian dapat disimpulkan, bahwa gangguan Mutisme Selektif pada anak adalah sebagai berikut: 1) Ketika di sekolah anak lebih cenderung diam bahkan tidak mau berbicara, sedangkan di rumah anak dapat berbicara secara bebas, 2) Anak lebih memilih menggunakan bahasa isyarat ketika berada di lingkungan luar rumah, 3) Anak lebih memilih ketika mau menjawab pertanyaan dari seseorang yang berada di lingkungan luar rumahnya dan melihat situasi tertentu, 4) Anak akan mau berbicara di lingkungan sekolah apabila anak diberikan dorongan dan nasehat, 5) Anak lebih memilih teman untuk diajak bermain dan tidak mudah berteman.

Faktor-faktor yang menyebabkan gangguan Mutisme Selektif pada anak EL adalah sebagai berikut: 1) Rasa malu dan kurang percaya diri yang sangat besar yang membuat anak tidak mau berbicara. 2) anak jarang bermain di luar lingkungan rumah. 3) Guru memberikan apresiasi ketika anak mau berbicara. 4) Tindakan orang tua yang melarang anak untuk bermain di luar rumah dan berbicara dengan orang yang baru dikenal.

Upaya yang dapat di lakukan guru dalam mengatasi gangguan Mutisme Selektif pada anak adalah sebagai berikur: 1) memberikan pendampingan pada anak dan motivasi kepada orang tua. 2) memberikan apresiasi terhadap anak saat anak mau berbicara. 3) Guru harus lebih selektif untuk memilih pertanyaan kepada anak. 4) berkomunikasi dengan orang tua secara rutin. 5) melakukan pendekatan yang intensif dengan anak. 6) Meningkatkan intensitas untuk mengenalkan anak dengan lingkungan baru.

\section{DAFTAR RUJUKAN}

Camposano, Lisa. 2011. Silent Suffering: Children with Selective Mutism. New Jersey : Prentice-Hall

Dewi, Rosmala. 2005. Berbagai Masalah Anak Taman Kanak-kanak. Jakarta: Depdiknas.

Hurlock,Elizabeth.1997. Psikologi Perkembangan Suatu Pendekatan Sepanjang Rentang Kehidupan.Jakarta:Penerbit Erlangga

Moleong, Lexy J. 2007. Metodologi Penelitian Kualitatif. Bandung Penerbit: PT Remaja Rosdakarya Offset

Morrison V, Bennet P. 2016. An Introduction to Health Psychology. Essex: Pearson education limited.

Nieves, M., dkk. 2012. Encyclopedia of human behavior (second edition). Orlando : Elsevier. 
Reber, A. S. 2010. Kamus psikologi. Yogyakarta: Pustaka pelajar.

Santrock, John W .2012.Life Span Development, Jakarta: Erlangga

Suhartono. 2005. Pengembangan keterampilan bicara anak usia dini. Jakarta: Depdiknas.

Tarigan, Henry G. 2013. BerbicaraSebagai suatu Keterampilan Berbahasa. Bandung:

CV.Angkasa.

Yanuarini, T. 2016. Hubungan Pengetahuan dengan Sikap Ibu. Banding : CV.Angkasa. 